\title{
Uzbekistan's Transformation with the New Uzbek Strategy: Shifting Policies towards Mediation of Labor Migration through Migration Infrastructure
}

\section{Zahide ERDOĞAN ${ }^{1}$}

\begin{abstract}
Because of the post-independence economic problems in Central Asian countries, Russia became the center of immigration, but as time passed, immigration shifted to Kazakhstan and Turkey. Uzbekistan is the most populous Central Asian country and the one that benefits the most from worker remittances. The New Uzbek Strategy, announced after Mirziyoyev's election in 2016, is transforming economy and society of the country. This paper aims to examine migration infrastructure through the New Uzbek Strategy as the way of protecting citizens abroad. It is critical to protect the rights of migrant workers in the destination countries to keep them from facing marginalization, exclusion, and poverty. Migration infrastructure is made up of regulatory, commercial, technological, humanitarian, and social elements. In this framework, the new Ministry of Labor structure, bilateral agreements, labor market regulation, allowing private recruitment companies, railway projects, development of cooperation with international organizations, and migrant networks all indicate the development of migration infrastructure components. In addition to economic liberalization, good neighborhood relations and foreign policy are important to develop migration infrastructure and institutionalization of migration. As a result, it is expected that the migration infrastructure development will increase migration, diversify of the countries and be beneficial to economic growth and transformation the country. Although these studies are still in their early stages, it has been concluded that significant steps have been taken in the infrastructure development, and the safe and regular migration will increase migration to the new destination countries in the future.
\end{abstract}

Key Words: Migration infrastructure, Labour Migrant's Rights, Uzbekistan's Transformation, Development, Migration Policy

\section{Özbekistan'ın Yeni Özbek Stratejisi ile Dönüşümü: Politikaların Göç Altyapısı Yoluyla Emek Göçünün Arabuluculuğuna Yönelik Değiştirilmesi}

\section{$\ddot{O} z$}

Orta Asya ülkelerinin bağımsızlık sonrası ekonomik sorunları Rusya’nın göç merkezi olmasını sağlamış, ancak zaman içinde göç Rusya ile birlikte gelişen Kazakistan ve Türkiye’ye yönelmiştir. Özbekistan Orta Asya ülkeleri içinde nüfusu en kalabalık ülke ve işçi dövizlerinden en çok yararlanan ülkedir. 2016 yllında Mirziyoyev'in seçilmesiyle açılanan Yeni Özbek Stratejisi ülkede ekonomik ve sosyal bir dönüşüm gerçekleştirmektedir. Bu makale, göç altyapısını yurtdışındaki vatandaşlarını korunmanın bir aracı olarak Yeni Özbek Stratejinden hareketle incelemeyi amaçlamaktadır. Göçmen işçilerin varış ülkelerinde haklarının korunması onların marjinalleşme, dışlanma ve yoksullukla karşılaşmasını önlemek için önemlidir. Göç altyapısı düzenleyici, ticari, teknolojik, insani ve sosyal bileşenlerden oluşmaktadır. Bu çerçevede, Çalışma Bakanlığının yeni yapısı, ikili anlaşmalar, iş piyasasının düzenlenmesi, özel işe alma şirketlerine izin verilmesi, demiryolu projeleri, uluslararası kuruluşlarla işbirliğinin geliştirilmesi ve göçmen ağları göç altyapısının bileşenlerinin geliştiğini göstermektedir. Ekonomik serbestleşmeyle birlikte komşularla iyi ilişkiler ve dış politika da göç altyapısının gelişmesinde ve göçün kurumsallaşmasında önemlidir. Sonuç olarak, göç altyapısı ile sağlanan gelişmenin göçü artıracağ1, göçün yöneleceği ülkeleri çeşitlendireceği ve ülkenin ekonomik büyümesi ile dönüşüm için etkili olacağı düşünülmektedir. Söz konusu çalışmalar henüz yeni olmakla birlikte altyapının gelişmesine ilişkin önemli adımlar atıldığı, gelecekte güvenli ve düzenli göçün artacağı ve yeni ülkelere yöneleceği sonucuna ulaşılmıștır.

Anabtar Kelimeler: Göç Altyapısı, Göçmen Hakları, Özbekistan’ın Dönüşümü, Kalkınma, Göç Politikası

\section{Atıf İçin / Please Cite As:}

Erdoğan, Z. (2021). Uzbekistan's transformation with the new Uzbek strategy: Shifting policies towards mediation of labor migration through migration infrastructure. Manas Sosyal Arastırmalar Dergisi, 10(ÖS), 157-171.

Geliş Tarihi / Received Date: 08.09.2021

Kabul Tarihi / Accepted Date: 24.09.2021

\footnotetext{
${ }^{1}$ Dr. - Yurtdışı Türkler ve Akraba Topluluklar Başkanlı̆̆ı, zahide.rdgn@gmail.com

(iD) ORCID: 0000-0002-0253-9355
} 


\section{Introduction}

After the collapse of the Soviet Union in 1991, Central Asia faced an increase in immigration as well as internal problems. Understanding migration from Central Asia requires knowledge of the historical context of the region as well as the ethnic structure that influences migration patterns. Since the late 1800 s, there has seen significant human mobility in this region, including forced migrations. As far as the places for settlement were determined by the State back in the days of the USSR period and the migration structure developed accordingly.

The origins of the five independent Central Asian countries go back to the opportunities given to establish themselves as modern nations between 1924-1936 and the establishment of the Soviet Union (Islamov, n.d.). The migration corridor from North and Central Asia is one of the largest and most popular and the destination countries for this region are Russia, which is estimated to employ about 10 million foreign workers, and Kazakhstan (UNESCAP, 2020). As of 2020, there are 281 million international immigrants worldwide and 51 million of them were born in Central and South Asia (United Nations Department of Economic and Social Affairs, Population Division, 2020, p. 15).

While the disintegration of the USSR in the 1990s caused conflicts in some of the Central Asian countries, it led to an increase in migration mobility in all of them. For example, ethnic Kazakhs, Turkmen, and Kyrgyz, who had to live in other regions due to the policies of the USSR, have returned to their historical homeland. Central Asian countries faced numerous economic, social, and political challenges after gaining independence, and problems arose as a result of the migration of ethnic Russians to Russia, particularly in terms of administrative experience (Abdullaeva, 2020, p. 40). The transition to a free-market economy has caused economic difficulties for the Central Asian countries, and in this period, labor migration from Uzbekistan, Kyrgyzstan and Tajikistan to Russia has started. While immigration occurred within the USSR until the 1990s, as the country disintegrated, Germans, Jews, and Greeks living in the USSR emigrated outside the country (IOM, 2008, p. 13). In the early years of independence of Uzbekistan, immigrants were mostly ethnic minorities like Russians, Ukrainians, and Jews, and the economic downturn in the 1990s, as well as open-door policies of Russia and Kazakhstan in the 2000s, increased labor migration (Kakhkharov et al., 2020, p. 5). According to some estimates, over 3 million Uzbeks work in Russia, though this figure may be misleading due to visa-free stay, seasonal workers, and unregistered workers (Kakhkharov et al., 2020, pp. 2-15).

In the process of a nation-state establishing, Uzbekistan, like other post-Soviet countries, faced various difficulties such as management, leadership, the market economy, human rights, and democracy, while ethnic conflicts and border wars posed challenges to political stability. Uzbekistan is the most populous country in Central Asia, bordering Turkmenistan, Kyrgyzstan, Tajikistan, Kazakhstan, and Afghanistan. The fact that the country is surrounded by five other countries has also influenced its foreign and defense policies (Fazendeiro, 2017, p. 410). The country is strategically important not only for its neighbors, but also for many other countries, as a result of projects such as the United States' Silk Road project, China's Belt and Road Initiative, the Iranian railway, and the trans-Afghan railway. Uzbekistan was economically and politically isolated during President Islam Karimov, who ruled the country from 1991 until he died in 2016 (Schmitz, 2020, p. 5).

The new President Shavkat Mirziyoyev started a series of reforms with the slogan "It is high time for the government to serve the people, not vice versa". Mirziyoyev has made numerous visits since he elected to strengthen ties with Central Asian countries and international organizations, as well as to maintain a balance of relations with the United States, China, and Russia. In his speech dated 22.12.2017, Mirziyoyev said, "The main priority of Uzbekistan's foreign policy is Central Asia."(President of the Republic of Uzbekistan, 2017). While these reforms have resulted in a new approach to Uzbekistan's foreign policy, a new regional approach has emerged. The steps towards the economic liberalization and foreign economic ties with neighboring countries and beyond demonstrate the country's efforts to become a hub not only for investments but also for transportation. This New Strategy approach is a sort of social contract in which the state serves the citizens and the citizens support the reforms. New Strategy of Uzbekistan 2017-2021 includes priorities in five areas, with openness politics, security and foreign policy, and economic liberalization as the most important aspect. Although migration and remittances have always been important for Uzbekistan, no further action on this issue was taken until 2016. 
Regular migration and migration infrastructure are important for sending countries to protect their citizens' rights abroad. Immigrants face numerous vulnerabilities and risks, in addition to poverty, and protecting immigrants' rights is critical to preventing the social and economic consequences of these vulnerabilities. The nature of vulnerabilities is also affected by the type of migration, and undocumented, unregistered migrants are more vulnerable to risks such as health problems (Sabates-Wheeler, \& Waite, 2003 , p. 13). The socio-political dimension of vulnerability results in the immigrant being illegal and undocumented, unable to benefit from socioeconomic opportunities in the country of destination, which can lead to the illegal immigrants' impoverishment, marginalization, exclusion, and discrimination (Sabates-Wheeler, \& Waite, 2003, p. 15). It is important to remember that the migrants may be legally present in their destination countries, for example, as tourists, but they will be unable to exercise their rights if they do not have a work permit.

This paper aims to examine migration infrastructure through the New Uzbek Strategy as a social process and means of protecting the rights of citizens abroad. Thus, this paper focuses on the role of migration infrastructure in initiating and encouraging migrations particularly concentrating on the countries with which Uzbekistan has signed treaties and the countries to which immigration will be directed. The role of migration infrastructure on the migration decision is not a new subject but using this concept to understand the effect of the New Uzbek Strategy on migration is a new way to think about possible immigration from Uzbekistan. There are studies on China and Indonesia (Xiang \& Lindquist, 2014), Japan and England (Sigona et al., 2021), and West Africa (Kleist \& Bjarnesen, 2019), where migration infrastructure is discussed with country examples. As far as we know, there has been no study that evaluates and discusses the impact of changes in migration infrastructure within the context of the New Uzbek Strategy. This study is expected to contribute to a better understanding of how migration infrastructure affects the countries to which migration will occur, as well as to update theory.

In this context, at first, the theory of migration and the concept of migration infrastructure were briefly discussed, and then, using the push-pull theory, the dynamics of migration in Post-Soviet Central Asia were broadly examined. Finally, the activities carried out within the framework of the New Uzbek Strategy are categorized and discussed in terms of regulatory, technological, commercial, human, and social dimensions. With the New Uzbek Strategy, direct or indirect efforts to establish migration infrastructure for labor migration demonstrate that migration is now more important to the country for liberalization, and it is being institutionalized through the regularization of the migration flow and providing protection for the citizens. According to Massey (1988, p. 396), once international migration reaches a critical mass, it will alter the social and economic structure of the country of origin, and migration will most likely continue. Thus, the institutionalization of migration is expected to result in a shift in social and economic structure of Uzbekistan but the efforts on this issue are relatively new and the structure requires improvement.

\section{Migration Theories and Migration Infrastructure}

Migration is a multidisciplinary field, and each discipline takes a different approach to determine the reasons for migration. For example, sociological approaches focus on attracting opportunities such as jobs available, institutions in facilitating the migration, networks and macroeconomic approaches focus on wage differentials between economies (Bijak, 2006, pp. 6-8). Migration is explained as a part of the economic structure in Neo-classical theories. Based on labor supply and demand, the neoclassical model predicts that the labor force will migrate from areas of surplus and low wages to areas of high demand and wages. The new economics of migration model, on the other hand, contends that migration decisions are made collectively, rather than individually, and that the immigrant seeks to maximize not only his income but also his status (Massey, 2015, pp. 466-467). Within the functionalist paradigm, the pull-push model, migration systems theory, and migrant networks can be considered, and migration is based on a costbenefit analysis of individuals and families (de Haas, 2021, p. 4). On the other hand, theories in the historical structural paradigm, such as conflict theory and world systems theory, are based on economic and power disparities between societies (de Haas, 2021, p. 4). Migration is a complex issue that must be evaluated alongside numerous economic, social, and political factors. While countries always want to predict migration toward them and to understand migration pattern, theories only allow for limited predictions. 
.

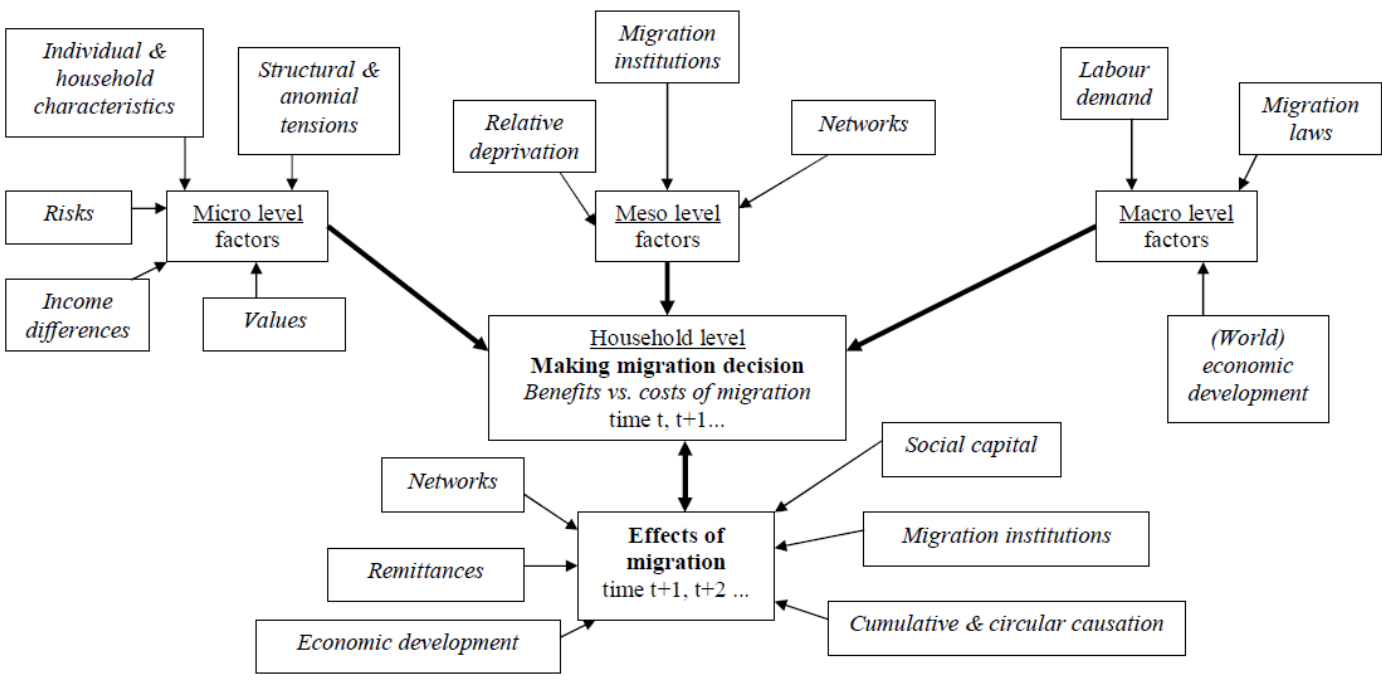

Figure 1. A General Framework for Migration Decision Making (Source: Hagen-Zenker (2008, p. 19)

Besides, Hagen-Zanker discussed migration theories as macro, micro, and meso theories, attempting to integrate them all into a single picture (Hagen-Zanker, 2008). Despite defining internal migration, Ravenstein's(1885) immigration laws served as the foundation for immigration theories. Lee attempted to explain the factors influencing migration decisions based on these laws by taking into account the positive and negative factors arising from the country of origin and destination, intervening obstacles and personal factors (Lee, 1966). Lee (1966, p. 51) points out personal characteristics, intelligence, awareness, and perception of the conditions in the country of origin all influence migration decisions, and these decisions are not always rational. However, the most significant issue with functionalist theories is their reducing nature; for example, the pull-push theory provides a list of migration factors but does not explain social processes and how these factors relate to each other as a migration drivers (de Haas, 2021, p. 6).

However, meso theories concentrate on factors such as social capital, networks, and migration institutions that facilitate migration (Figure 1). Massey et al. (1987, p. 317) concluded in social capital theory that social networks such as family and relatives will lower the cost of migration; as this network grows, more people will migrate; and, eventually, everyone will have this social network. Additionally, using Gidden's theory of structuration and the example of the Philippines, Goss and Lindquist (1995) used the concept of migrant institutions as a meso level element of analysis in understanding international labor migration. For example, the Philippines attempted to regulate immigration by signing bilateral treaties and allowing private recruitment agencies, and immigration has now become institutionalized through immigrant networks and external migrant institutions such as brokers, recruitment agencies and NGOs (Goss \& Lindquist, 1995).

However, Massey (2015, p. 466) divides migration theories into five categories: structural forces in the sending country, structural forces in the receiving country, the purpose of the immigrant, the formation of social and economic fields that will allow immigration, and policies in the countries that affect the flow of immigrants. To comprehend migration, it is necessary to consider the policies of governments, businesses, recruitment agents and migration intermediaries, as well as international organizations such as UNHCR and IOM, to shape migration and create new migration patterns (de Haas, 2021, pp. 6-7). A similar approach to the institutionalization of migration is the concept of migration infrastructure. Xiang and Lindquist (2014, pp. 143-144) point out that migration infrastructure explains how Europe does not passively accept immigrants but actively builds it through regional relations, as well as social change through migration in China and Indonesia. Xiang and Lindquist (2014, p. 124) investigated the components that facilitate migration using the concept of migration infrastructure and defines the concept as follows:

For analytical purposes, we stipulate five dimensions of migration infrastructure: the commercial (recruitment intermediaries), the regulatory (state apparatus and procedures for documentation, licensing, training and other 
purposes), the technological (communication and transport), the humanitarian (NGOs and international organizations), and the social (migrant networks). (Xiang \& Lindquist, 2014, p. 124)

The concept of migration infrastructure is an overarching concept that helps to understand the factors that mediate migration. The migration infrastructure can increase mobility with the expansion of regulatory capacity of the state and market, and in Asia and the Middle East, there is a greater focus on the sending state's migration infrastructure, such as health certification and training (Xiang \& Lindquist, 2014, p. 125). According to Xiang and Lindquist (2014, p. 132), migration infrastructure focuses on how migration is mediated rather than migration behavior; while the migration flow is temporary, the infrastructure maintains a level of stability, which distinguishes it from the migration system and mobility regime. Existing theories ignore the impact of forced migration and immigration policies, and economic theories ignore the effects of post-socialist transformations (Bijak, 2006, p. 16). So, the institutionalization of migration should be discussed in light of socioeconomic transformation rather than economic theories in Uzbekistan. As a result, migration infrastructure is a structure that likely allows for the establishment of a permanent structure beyond the factors that impact migration decisions and would accompany societal change.

\section{Migration Dynamics in Post-Soviet Central Asia}

With disintegration of Russia, a new wave of migrants from CIS emerged. The majority of Central and Eastern European immigrants went to Western Europe, while the majority of Central Asian immigrants went to other CIS countries, such as the wealthier Kazakhstan and Russia (Mansoor \& Quillin, 2006, p. 24). The total number of international migrants during this period is difficult to estimate. In terms of labor migration, the statistics will be meaningless because movements that were previously considered internal migration and those who migrated to their own countries ethnically will all be considered immigrants (Mansoor \& Quillin, 2006, pp. 28-29). On the other hand, statistics only show those who have legally settled in Russia, and it is widely assumed that only $10 \%$ of foreign workers in Russia have legal documents (Laruelle, 2007, p. 104). In the 1990s, Uzbekistan was a receiving country for immigrants from Afghanistan and Tajikistan, but it later became a sending country for labor to Russia (Laruelle, 2007, p. 104).

Uzbekistan and Kazakhstan have been the Central Asian countries with the highest number of immigrants. Russia, Kazakhstan and Turkey are one of the most important migration destinations of Uzbekistan. The pattern of immigration between Uzbekistan and Russia, as well as between Uzbekistan and Turkey, is influenced by a variety of economic, historical, cultural, linguistic, and political factors. The population of Uzbekistan is estimated at 15.899 .000 in 1980, 20.398.000 in 1990, 24.770.000 in 2000, 28.516.000 in 2010 and 32.982.000 in 2020 (United Nations, Department of Economic and Social Affairs, 2021). Along with the population of Uzbekistan, labor migration has also increased regularly. According to UN estimates, there were 1.428.000 Uzbek migrant workers in 1990, 1.575.969 in 2000, 1.880.557 in 2010, and 1.979.523 in 2019 (United Nations, Department of Economic and Social Affairs. Population Division, 2019). Kazakhstan, the country with the highest number of immigrants, the number of immigrants increased from about 3 million in 1990 to 4 million in 2019 (United Nations, Department of Economic and Social Affairs. Population Division, 2019). However, it is necessary to compare the number of immigrants to the country's population. Kazakhstan, Kyrgyzstan, and Uzbekistan have the highest proportions of emigrants in the region. As a result, immigrants account for 22 percent population of Kazakhstan, 6 per cent population of Uzbekistan, and 12 per cent population of Kyrgyzstan (United Nations, Department of Economic and Social Affairs. Population Division, 2019).

Migration is always a complicated and sensitive issue, with many positive and negative consequences for both sending and receiving countries. Initially, immigrants were considered as a threat to national identity and harmony, but they were later viewed as a threat to security. While immigrants are a short-term safety valve for the sending country, the importance of remittances has led to the consideration of immigrants as a means of development (Castles et al., 2008, p. 19). As a result of remittances, migrant workers have grown in importance for their home countries and are now being discussed as a driving force in their development. Uzbekistan has the highest amount of remittances among Central Asian countries, and it is estimated that worker remittances, which were 4.843 million USD in 2015, increased to 6.989 million USD in 2020 (World Bank, 2021c). Accordingly, remittances account for 12.1 percent GDP of Uzbekistan. Furthermore, the amount of remittances sent to Kyrgyzstan is 2.200 million USD, with a 
share of GDP of 29.4 percent for 2020, while the amount of remittances sent to Tajikistan is 2.187 million USD, with a share of GDP of 27.3 percent (World Bank, 2021c)

Top five trading partners of Uzbekistan are China, Russia, Kazakhstan, Korea, and Turkey in 2020. (Figure 2). Uzbekistan and South Korea have a trading volume of 2.36 billion dollars, and Uzbekistan is the third-largest trade partner of South Korea in 2019 (Nikolova, 2021). China, the world's largest exporter, is a significant investor in Uzbekistan but according to the Central Asia Barometer 2020 data, while 65 per cent welcomed Chinese investments in 2019, this rate fell to 48 per cent in 2020, indicating that there is growing skepticism about Chinese investments (Nikolova, 2021). In 2019, foreign direct investments in Uzbekistan increased to 2.3 billion dollars, accounting for 4\% of GDP (World Bank, 2021a). The Presidency's office, on the other hand, announced that FDI investments in Uzbekistan in 2020 totaled 6.6 billion dollars, with a target of 7.6 billion dollars for 2021 (ANI, 2020).

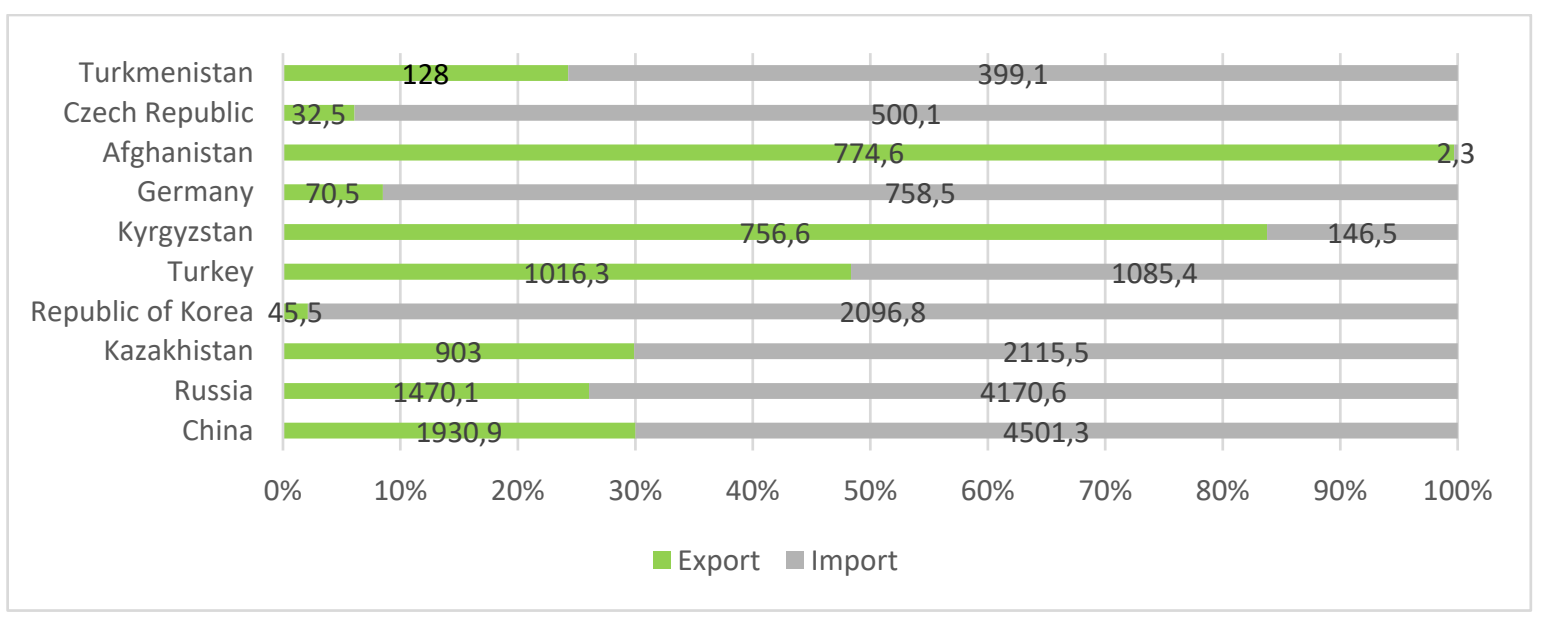

Figure 2. Uzbekistan's Top Trading Partners, 2020, Million USD (Source: UZSTAT, 2021, p. 2)

Migration decisions are frequently explained by economic and demographic, political, and social and cultural push and pull factors, and migration results from wage differences between markets, according to the most basic economic models (Mansoor \& Quillin, 2006, p. 77). So, one of the most important reasons for migration is wage differences between countries and Harris and Todaro (1970) focus on expected income rather than actual income. According to World Bank data, Uzbekistan's per capita income in 2020 was 1.685 USD, while Turkey's was 8.538 USD and Russia's was 10.126 USD (World Bank, 2021b). For example, Uzbek immigrants who are unable to travel to Russia due to Covid-19 work in Kyrgyzstan on an informal basis. Migrant workers earning $\$ 130$ per month in Uzbekistan, for example, can earn $\$ 10-20$ per day in Kyrgyzstan (Radio Free Europe Radio Liberty, 2021). Wage disparities in general can thus be used to explain immigration in this region.

Russia is the first destination country for Uzbek workers, and the policy of Russia and pull factors play an important role in explaining why people migrate to this country. Because of Russian population structure and declining population, immigration is necessary to compensate for the labor market needs. The population of Russia was 102.799.000 in 1950, 130.149.000 in 1970, 147.532.000 in 1990, 146.405.000 in 2000, 143.479 .000 in 2010 and 145.934 .000 in 2020. It is predicted that the population will fall to 130 million by 2030 (United Nations, 2020). In the first half of 2019, 2.4 million foreigners came to Russia to work, and the number of workers from the CIS is predominant (RBC, 2019). According to FSB border service data, 918.000 migrant workers arrived in Russia in first half of 2019 from Uzbekistan, 524.000 from Tajikistan, 265.000 from Kyrgyzstan, 165.000 from Ukraine, and 105.000 from Kazakhstan (RBC, 2019). As a result, Russia remains the country to which Uzbekistan sends the most workers and Uzbek migrant workers make up 38\% of the total migrant workers. Furthermore, Putin signed an immigration policy plan that calls for the citizenship of 5-10 million migrant workers from Ukraine, Kazakhstan, Uzbekistan, Moldova, and other former Soviet Russian-speaking countries in order to meet the needs of a declining population from 2019 to 2025 (The Moscow Times, 2019). As a result, Russia's policy of granting citizenship to immigrants will have an impact on the direction of migration.

Visa-free travel between countries is other factor that facilitates migration. Migration policies of the countries generally address issues such as border controls, visa policies, and integration. In this context, Russia's immigration policy is based on quotas and work permits to control entry into the labor market, 
rather than border controls for visa-free CIS countries (Schenk, 2010, p. 105). Citizens of CIS member countries can stay in Russia without registering or obtaining a visa for up to 90 days every six months, for a total of 180 days every year. There are differences between countries; citizens of Tajikistan can stay in Russia without registering for up to 15 days, while citizens of Kazakhstan and Belarus can stay for up to 30 days (V.I. Vernadsky Crimean Federal University, 2015). Central Asian countries are among those where Turkey offers visa-free entry for up to 90 days (Göç İdaresi Genel Müdürlüğü, 2020). According to Turkish Statistical Institute data, 127.322 people immigrated to Turkey from Central Asian countries between 2016 and 2019, with women accounting for 16.730 of the 25.064 people who immigrated from Uzbekistan (TÜİK, 2020).

Immigrant networks, as well as linguistic and cultural proximity, play an important role in explaining migration to countries. Although the Soviet-era migrant networks remain influential, migration from Central Asian countries is now directed not only to Russia, but also to Kazakhstan, which is now more economically developed, particularly from Kyrgyzstan and Uzbekistan (Laruelle, 2007, p. 105). Kazakhstan has been new migration center for Central Asian countries since 2000, and especially Russia attractive for Tajikistan, Kyrgyzstan, and Uzbekistan, but the number of those who went to EU countries with a work permit increased by 14 percent between 2016 and 2019, and it was seen that especially Kazaks and Uzbeks migrated to South Korea (Khashimov et al., 2020, pp. 1-2). Although it is expected that the aforementioned immigrant networks will remain effective, it is also expected that networks will form in new countries as a result of the New Uzbek Strategy.

\section{New Uzbek Strategy and Migration Infrastructure}

Following the election of Shavkat Mirziyoyev as President, a strategy document covering the years 2017-2021 was prepared for Uzbekistan, with the goal of developing in five areas. The following are the document's priority areas: state and public construction, democratization and improving the judicial system, economic development and liberalization, development of social sphere, ensuring security, interethnic harmony and religious tolerance, foreign policy (The Tashkent Times, 2017). Mirziyoyev's strategy includes two key elements: economic liberalization to ensure the country's growth and strengthening the role of political parties, civil society, and parliament (Schmitz, 2020, p. 12). Furthermore, constructive foreign policy, along with ethnic harmony and religious tolerance, was included as a security priority in the New Strategy (The Tashkent Times, 2017).

Unemployment is a major issue in Uzbekistan, which has a rapidly growing population, and some arrangements have been made within the framework of the New Strategy to ensure regular and safe labor migration. Labor migration has always been important for Uzbekistan; however, despite the previous administration's efforts to patch some regulations, regular migration was not possible due to bureaucratic issues, a lack of bilateral or multiple agreements, and legal issues (Sibagatulina, 2021, p. 2). First and foremost, a structure was created to institutionally support labor migration. The Ministry of Labor's structure was altered to include the social protection mandate in the New Strategy, and the Foreign Labor Migration Agency was established to assist those who wish to work abroad (Sibagatulina, 2021, p. 3). Furthermore, with the new President's decree in 2017, it was announced that as of 2019, no government permission will be required when travelling abroad (Seitz, 2019, p. 2). To regulate labor migration abroad, offices will be opened in foreign countries, private employment agencies within the country could make labor agreements, and a fund application was initiated. In this framework, offices will be established in Istanbul, Dubai, and four Russian cities in 2021 to negotiate labor agreements, and private employment agencies will be established in Uzbekistan to recruit workers who will work abroad (Sibagatulina, 2021, p. 3). In addition, a fund has been established to protect the rights of Uzbeks living abroad, cover medical expenses, and provide social, financial legal assistance (Sibagatulina, 2021, p. 3). As an example of commercial infrastructure, recruitment agencies can also provide diversity in the destination countries of Uzbek immigrants.

One of the pillars of the new Uzbek strategy is ensuring regular, safe, and legal immigration. To that end, an action plan has been developed to provide migrant workers with vocational and language training, to submit internationally valid documents, and to provide financial and social support to migrants in distress. (Sibagatulina, 2021, p. 7). As a result, developing employee capacity through training and assisting those who face difficulties are approaches that both aim to increase labor migration while prioritizing the 
safety of Uzbek immigrants. Capacity building and social protection of their citizens abroad are critical, particularly for Uzbekistan, which has a high rate of unregistered labor migration.

The economy is a prominent component in foreign policy strategies under the New Strategy. It aims, for example, to establish a neighborhood based on good relations around Uzbekistan, and to develop foreign policy, foreign economic activities, and international cooperation (The Tashkent Times, 2017). Signing bilateral and multilateral agreements with countries, as well as collaborating with international organizations, are also important tools for ensuring migration infrastructure. Other than labor migration regularization, the strategy document covers events in a variety of fields, collaboration with institutions and companies such as GIZ, the World Bank, USAID, and Chinese Huawei to prepare domestic and international projects, as well as mobilize young people and the media, is one of them (Schmitz, 2020, pp. 13-14). In terms of trade, the development of regional neighborhoods is also important. During Mirziyoyev's tenure, for example, relations with Tajikistan and Kyrgyzstan improved, water management and border issues were resolved, and scheduled flights with Tajikistan began (Schmitz, 2020, p. 24). As a result, foreign policy priorities are based on the development of relations and economic development, particularly with the countries in the region.

During Karimov's tenure, Uzbekistan's relations with China, South Korea, Russia, and Japan were security-oriented, based on Karimov's policy of continuing his life and cooperation has now evolved and gone beyond security. For example, the roadmap for economic cooperation with China was signed in May 2017, the roadmap for economic cooperation with South Korea was signed in November 2017, and changes were made in the previously existing agreement with Japan in 2018 (Dadabaev, 2020). These agreements envisage the opening of offices in countries to regulate and increase labor migration, as well as increasing investments and exports in these countries (Dadabaev, 2020, p. 184). Important names from South Korea have been appointed as advisors in Uzbekistan's ministries, demonstrating that the relationship between Uzbekistan and Korea extends beyond economic cooperation to Uzbekistan's modernization (Dadabaev, 2020, p. 185). Labor migration is a key agenda item in all of these cooperative efforts; in other words, Uzbekistan is also establishing migration infrastructure not only through economic liberalization but also through constructive foreign policy.

Uzbekistan establishes relations not only with Central Asian countries, but also with China, Russia, Iran, Afghanistan, and Pakistan, and signs treaties to reach seaports. China's Belt and Road Initiative affects more than 60 countries and has been supported by Uzbekistan since its beginning. China is the largest trading partner of Uzbekistan, and it is predicted that this project will boost regional trade, create new jobs, support human resources development, and attract tourists (Development Strategy Center, 2019). While Uzbekistan continues the railroad project that begun with Iran in 2011, it held talks with the Afghan administration, the Taliban, and Pakistan for the trans-Afghan railroad in April 2021 (Hashimova, 2021). By providing access to seaports, both projects are likely to pave the way for economic development in Uzbekistan and Central Asian countries. Although Uzbekistan has also met with the Taliban for the trans-Afghan railroad project, it is important how the Taliban's takeover of power in Afghanistan in August will affect these projects and especially the mobility between the two countries.

Although relations with Russia are always important for historical, cultural, and economic reasons, the liberal foreign economic policy also influenced the development of trade with Russia; trade between two countries increased despite the epidemic, and Mirziyoyev activated military-technical cooperation (Yakubov, 2021). Uzbek immigrants are the lowest paid group in Russia, and poor living conditions and worker discrimination are common complaints among Central Asian immigrants in Russia, China, and South Korea (Schulz, 2021). According to a study conducted by the Moscow-based Levada Centre, 71\% of respondents support the slogan "Russia for Russians," and the government has no interest in the rising anti-immigrant sentiment (Schulz, 2021). The rise of anti-immigrant sentiment and the perception of immigration as a security threat have the potential to impede the flow of people from Uzbekistan to Russia. Kyrgyzstan is an EAEU member, even though immigrants in Russia have the right to preferential social security and health care, they face discrimination. Although, Uzbekistan signed three bilateral agreements with Russia in 2007, none of them has been implemented (Schulz, 2021). As a result, it is difficult to predict how effective the agreements signed under the new Uzbek Strategy will be in ensuring the safety and rights of migrant workers.

Diplomatic relations between South Korea and Uzbekistan were established in 1992, and cooperation in a variety of fields, including trade and education, was initiated. South Korea is an important trade 
partner for Uzbekistan, and the Korean diaspora in Uzbekistan plays an important role in bilateral relations. South Korea's liberal economy, proximity to the region, and desire to recruit Central Asian workers have all contributed to an increase in the number of immigrants to the country (Schulz, 2021). Despite differences in language, religion, and tradition, as well as geographical distance, the number of immigrants to South Korea is growing. According to Korean statistical data, the number of Uzbeks living in South Korea increased from 14,246 in 2015 to 25,961 in 2019 (Dadabaev \& Soipov, 2020, p. 123). Dadabaev and Soipov (2020, p. 135) point out that although the number of Uzbek immigrants going to Japan and South Korea for work or education is growing, they usually intend to return in the shortmedium term due to religious and identity differences.

Turkey and Uzbekistan established diplomatic relations in 1991, and the two countries have over 100 agreements and protocols in place as of 2019. However, relations between the two countries took a new turn following the 2016 Samarkand summit (Kemaloğlu, 2020). In 2019, Uzbekistan joined the Turkic Council, flights between the two countries began, Ziraat Bank opened a branch in Uzbekistan, and Turkish citizens were granted visa liberalization for 30 days (Kemaloğlu, 2020). As of 2019, trade between Turkey and Uzbekistan totaled 2.3 billion dollars, with 1300 Turkish companies operating in the country (Republic of Turkey Ministry of Foreign Affairs, 2021). In addition, Turkey and Uzbekistan signed an agreement in 2018 to protect the rights of workers and their families. Migrant workers from Uzbekistan also come to Turkey with irregular status, usually seasonal work or to stay within the framework of visa liberalization. All of these efforts and agreements demonstrate that arrangements have been made for the establishment of migration infrastructure to protect citizens beyond the existing historical and cultural ties between the two countries.

The humanitarian dimension of migration infrastructures necessitates cooperation with NGO and international organizations. Regular and legal migration is also one of the New Strategy's aims, and the Ministry of Employment and Labor Relations is collaborating with the ILO on the project "Capacity building in the field of preventing human trafficking in Uzbekistan" to combat human trafficking and provide preventive measures (MEHNAT, 2021b). Furthermore, collaboration with the International Organization for Migration (IOM) on the establishment of an office in Tashkent, the development of legal mechanisms to assist migrants, and the regulation of migration flow continue (MEHNAT, 2021a). Furthermore, the Ministry's collaboration with international organizations to regulate labor migration is just one example of the institutionalization efforts to build the migration infrastructure. In other words, Uzbekistan is systematically institutionalizing its efforts to build a migration infrastructure. Xiang and Lindquist (2014, p. 136) state that the growth of one component causes the growth of the other, thus establishing the mechanism of the infrastructure. Uzbekistan has already taken steps in this framework to address the five components of its migration infrastructure. It is clear that regulatory measures are prominent, and the development of this component will result in the development of other components (Figure2).

$\begin{gathered}\text { Private recruitment } \\ \text { agencies }\end{gathered}$
(2)

Figure 3. Migration Infrastructure of Uzbekistan

By removing the regulations that previously prevented international migration and beginning to build the migration infrastructure, Uzbekistan gives the impression that migration will be used as leverage for economic liberalization and growth, and also protection of their citizens. The removal of the procedure for obtaining permission to travel abroad, the restructuring of the Ministry of Labor, and the establishment of offices for labor migration abroad demonstrate the improvement on the regulatory dimension of the infrastructure. On the other hand, it is noted that the commercial dimension is established by allowing private recruitment agencies, and the government has also planned language and 
orientation training to improve the capacities of those who will work abroad. As a result, progress in the regulatory and commercial migration infrastructure dimensions is very clear.

Transportation and communication advancements are part of the technological dimension of migration infrastructure. The technological dimension will provide a network for the flow of ideas, goods and people. The fact that Uzbekistan has begun to resolve its issues with Kyrgyzstan and Tajikistan, as well as the increase in flights, exemplifies both constructive foreign policy and migration infrastructure. Railway projects such as the Iranian railway, the trans-Afghan railway, and the "One Belt One Road" project will provide opportunities for migration as well as trade.

The humanitarian dimension is an important component of the migration infrastructure. In other words, collaboration with international organizations and non-governmental organizations (NGOs) is critical in combating human trafficking, undocumented immigrants, discrimination, and abuse of immigrants. The New Uzbek Strategy prioritizes security and social protection. In this regard, it is critical to apply funds for those who are having problems abroad to ensure the safety and protection of their citizens. As a result, the humanitarian dimension emerges as an area where measures in migration infrastructure are taken. The last dimension of the infrastructure is the social dimension. Uzbek people are minorities in Russia, Afghanistan, and China, as well as other CIS countries, and there is Uzbek diaspora in many countries, including Turkey, Pakistan, Saudi Arabia, and the United States even South Korea. As a result, it is assumed that they have an adequate migrant network.

While the majority of Uzbek immigrants go to Russia, Kazakhstan, and Turkey, the number of Uzbek immigrants who go to South Korea has also increased. Although cultural proximity and language can explain the history of migration from Uzbekistan to Russia and Turkey, there is a large Uzbek community in South Korea that cannot be explained because of religious, linguistic, and cultural differences. Migration to countries such as South Korea and Japan can be explained by institutionalization of migration. Aside from labor migration, there are also those who travel to Japan and South Korea for education. Higher education enrolment is growing as a result of these countries' scholarship programs and agreements. Although, Russia has always been a popular destination for Uzbek immigrants, discrimination in Russia, as well as physical and verbal insults directed at Central Asian and, in particular, Uzbek immigrants, may lead to migration to other countries via the migration infrastructure provided by the new Uzbek Strategy. Some education migration to Turkey is directed to these countries under the auspices of the Great Student Project and Turkey Scholarships. On the other hand, it is necessary to take into account the findings of Dadabaev and Soipov (2020, p. 135) that educational migration to South Korea and Japan is complex and short-term with labor migration.

Xiang and Lindquist (2014, p. 122) state that "Migration infrastructure is the systematically interconnected technology, institutions, and actors that facilitate and condition mobility"; in other words, migration should be considered as the entire system, not just individual migration. They also emphasize that migration cannot be explained by a single factor, such as the labor market or government policies, but must be considered in conjunction with the entire migration infrastructure. Taking into consideration the new regulations in Uzbekistan, all dimensions of migration infrastructure and institutionalization are expected to grow. The development of migration infrastructure, along with economic liberalization, is likely to provide protection for migrant workers, ensure safe migration, and support socioeconomic transformation of the country. However, steps have been taken by Uzbekistan since Shavkat Mirziyoyev's election to develop migration infrastructure to ensure socio-economic development of the country, the fact that the process is still in its early stages has made it difficult to fully evaluate the reforms from the perspective of migration infrastructure.

\section{Conclusion}

Migration is a global and multifaceted issue, and it has become an important issue for CIS countries since the collapse of the Soviet Union. Labor migration is important for Uzbekistan, the region's most populous country, in terms of remittances and as a safety valve against unemployment. However, given the numerous vulnerabilities associated with being a migrant, the sending immigration infrastructure of the country is critical for protecting immigrants' rights in their destination country and avoiding negative consequences such as poverty and exclusion. Uzbekistan is undergoing a transformation in the fields of migration management, economy, and foreign policy as part of the New Uzbek Strategy, which was initiated with the election of Mirziyoyev. The purpose of this paper is to examine migration infrastructure through the New Uzbek Strategy as social process and means of a protection mechanism for labor 
migration. The concept of migration infrastructure is not a new one, but to the best of our knowledge, no research on Uzbekistan has been found within the framework of this concept. The migration infrastructure aspect of initiating and promoting migration is the focus of this paper. Even though various theories have been developed to explain migration, the concept of migration infrastructure was chosen because economic theories are deemed insufficient to explain post-socialist transformations.

Within the pull and push factor framework, migration is frequently explained by economic and demographic, political, and social and cultural factors. Pull and push factors give a kind of list related to migration drivers. But, understanding migration patterns, social processes, and migration at a structural level requires more than just explaining migration in terms of migration decisions. Due to the historical ties and language Russia, economically growing Kazakhstan and Turkey are important destination countries for CIS countries. Russia, China, Turkey, and South Korea are important trade partners of Uzbekistan. Despite language and cultural differences, South Korea and Japan are seeing an increase in immigration from Uzbekistan. Although a visa-free regime between countries attracts migrant workers, it also increases unregistered labor migration to Uzbekistan. Therefore, the data on the number of migrant workers in this region are only estimates and the majority of migrant workers are seasonal and unregistered as a migrant worker. This situation complicates the security and protection of migrant workers' rights. Demographic and economic factors are the most important driving forces behind Uzbek immigration. On the other hand, it is possible to argue that the significance of historical ties and language has declined, particularly in terms of immigration to countries such as South Korea and Japan.

Migration infrastructure, according to Xiang and Lindquist, has five dimensions: regulatory, technological, commercial, humanitarian, and social. The New Uzbek Strategy's priorities of economic liberalization, constructive foreign policy, and security also ensure the development of migration infrastructure. Uzbekistan implements a series of preventive and transformative policies aimed at increasing regular and safe labor migration and providing social protection and legal support to their people abroad. The restructuring of the Ministry of Labor, the opening of offices in countries, the establishment of private recruitment agents, and the establishment of funds to assist workers abroad demonstrate the regulatory and commercial dimensions of migration infrastructure. Furthermore, Agreements with neighboring CIS countries, South Korea, China, Russia, and Turkey aim to increase trade while also securing migration. The technological dimension of migration infrastructure also includes Iran railroad, China's One Belt One Road Initiative, and trans-Afghan railroad projects. Furthermore, migration infrastructure of Uzbekistan has provided a humanitarian dimension by developing cooperation with international organizations, as well as a social dimension through the immigrant network established by the Uzbek diaspora in other countries.

In conclusion, while assessing the impact of developments within the framework of Uzbekistan New Strategy is early, the country has made progress on all components of its migration infrastructure. A foreign policy based on constructive policy is used for also safe and regular migration from Uzbekistan to destination countries. It is estimated that the steps taken regarding to the migration infrastructure will lead to the increase in migration not only to Russia, Turkey and Kazakhstan but also South Korea and Japan. Besides, the institutionalization of migration is expected to result in economic growth and social transformation in the future with market-oriented reforms of Uzbekistan.

\section{Ethical Declaration}

In the writing process of the study titled 'Uzbekistan's Transformation with the New Uzbek Strategy: Shifting Policies towards Mediation of Labor Migration through Migration Infrastructure", there were followed the scientific, ethical and the citation rules; was not made any falsification on the collected data and this study was not sent to any other academic media for evaluation. Since the document review was conducted in this study, there is no need for an ethics committee decision.

\section{References}

Abdullaeva, N. (2020). Tertiary student migration from Central Asia to Germany: Cases of Kazakhstan, Kyrgyzstan and Uzbekistan. Springer Fachmedien Wiesbaden. https://doi.org/10.1007/978-3-658-29020-7

ANI. (2020, December 24). Uzbekistan attracts USD 6.6 billion foreign direct investment in 2020. ANI News. https://www.aninews.in/news/world/asia/uzbekistan-attracts-usd-66-billion-foreign-direct-investment-in202020201224120017/ 
Bijak, J. (2006). Forecasting international migration: Selected theories, models, and methods [CEFMR Working Paper]. Central European for for Migration Research. https://pdfs.semanticscholar.org/c67f/39cc621207bf34c63f371108a6021102744f.pdf?_ga=2.96226204.126208 $9157.1504957568-460371594.1504957568$

Castles, S., \& Delgado Wise, R. (2008). Migration and development: Perspectives from the South. IOM International Organization for Migration.

Dadabaev, T. (2020). De-securitizing the "Silk Road": Uzbekistan's cooperation agenda with Russia, China, Japan, and South Korea in the post-Karimov era. Journal of Eurasian Studies, 11(2), $174-187$. https://doi.org/10.1177/1879366520943896

Dadabaev, T., \& Soipov, J. (2020). Craving jobs? Revisiting labor and educational migration from Uzbekistan to Japan and South Korea. Acta Via Serica, 5(2), 111-140. https://doi.org/10.22679/AVS.2020.5.2.005

de Haas, H. (2021). A theory of migration: The aspirations-capabilities framework. Comparative Migration Studies, 9(1), 8. https://doi.org/10.1186/s40878-020-00210-4

Development Strategy Center. (2019, Noc). Development strategy center “One Belt, One Road”: Four initiatives of the President of Uzbekıstan. https://strategy.uz/index.php?news=693\&lang=en

Fazendeiro, B. T. (2017). Uzbekistan's defensive self-reliance: Karimov's foreign policy legacy. International Affairs, 93(2), 409-427. https://doi.org/10.1093/ia/iiw062

Göç İdaresi Genel Müdürlüğü. (2020, March 1). Türkiye'nin vize muafiyeti tanıdığı ülkeler. https://www.goc.gov.tr/turkiyenin-vize-uygulamadigi-ulkeler

Goss, J., \& Lindquist, B. (1995). Conceptualizing international labor migration: A structuration perspective. International Migration Review, 29(2), 317-351. https://doi.org/10.2307/2546784

Hagen-Zanker, J. (2008). Why do people migrate? A review of the theoretical literature (Working Paper MGSoG/2008/WP002; Issue MGSoG/2008/WP002). Maatricht Graduate School of Governance.

Harris, J. R., \& Todaro, M. P. (1970). Migration, unemployment and development: A two-sector analysis. The American Economic Review, 60(1), 126-142.

Hashimova, U. (2021, April 19). Uzbekistan pushing to realize the Trans-Afghan Railroad. The Diplomat. https:/ thediplomat.com/2021/04/uzbekistan-pushing-to-realize-the-trans-afghan-railroad/

IOM. (2008). Migration in the Russian Federation: A Country Profile $2008 . \quad$ IOM. https://publications.iom.int/books/migration-russian-federation-country-profile-2008

Islamov, B. (n.d.). Central Asian population in historical perspectives. Retrieved 29 August 2021, from https://www.ier.hit-u.ac.jp/COE/Japanese/Newsletter/No.14.english/Islamov.htm

Kakhkharov, J., Ahunov, M., Parpiev, Z., \& Wolfson, I. (2020). South-South migration: Remittances of labour migrants and household expenditures in Uzbekistan. International Migration, $\mathrm{n} / \mathrm{a}(\mathrm{n} / \mathrm{a})$. https://doi.org/10.1111/imig.12792

Kemaloğlu, İ. (2020, February 21). Mirziyoyev'in ziyareti çerçevesinde Türkiye-Özbekistan ilişkileri [Anadolu Ajans1]. https://www.aa.com.tr/tr/analiz/mirziyoyev-in-ziyareti-cercevesinde-turkiye-ozbekistan-iliskileri/1740453

Khashimov, S., Aisarina, Z., Nuranova, K., \& Zhandayeva, R. (2020). Introducing the Central Asia migration tracker. The Oxus Society for Central Asian Affairs. https://oxussociety.org/wpcontent/uploads/2020/12/introducing-the-central-asia-migration-tracker-2.pdf

Kleist, N., \& Bjarnesen, J. (2019). MIASA WP_2019(3) Kleist_Bjarnesen_2.pdf [MIASA Working Paper No 2019 (3)]. University of Ghana. https://www.ug.edu.gh/mias-africa/

Laruelle, M. (2007). Central Asian labor migrants in Russia: The 'Diasporization' of the Central Asian States? China and Eurasia Forum Quarterly, 5(3), 101-119.

Lee, E. S. (1966). A theory of migration. Demography, 3(1), 47-57.

Mansoor, A., \& Quillin, B. (2006). Migration and remittances: Eastern Europe and the Former Soviet Union. The World Bank. https://doi.org/10.1596/978-0-8213-6233-4

Massey, D. S. (1988). Economic development and international migration in comparative perspective. Population and Development Review, 14(3), 383. https://doi.org/10.2307/1972195

Massey, D. S. (2015). Migration, Theory of. In International Encyclopedia of the Social \& Behavioral Sciences (Vol. 15, pp. 466-471). Elsevier. https://doi.org/10.1016/B978-0-08-097086-8.31119-9

Massey, D. S., Alarcon, R., Durand, J., \& Gonzalez, H. (1987). Return to Aztlan: The social process of international migration from western Mexico. University of California Press.

MEHNAT. (2021a, March 18). The Ministry of Employment and Labour Relations held a meeting with representatives of the International Organization for Migration. Ministry of Employment and Labor Relations of the Republic of Uzbekistan. https://mehnat.uz/en/news/the-ministry-of-employment-and-labour-relationsheld-a-meeting-with-representatives-of-the-international-organization-for-migration

MEHNAT. (2021b, August 19). The project "Capacity building in the field of preventing human trafficking in Uzbekistan" was presented. Ministry of Employment and Labor Relations of the Republic of Uzbekistan. https://mehnat.uz/en/news/the-project-capacity-building-in-the-field-of-preventing-human-trafficking-inuzbekistan-was-presented

Nikolova, M. (2021, January 22). South Korea is becoming a real alternative to Russia and China in Central Asia. Emerging Europe. https://emerging-europe.com/news/south-korea-is-becoming-a-real-alternative-to-russiaand-china-in-central-asia/ 
President of the Republic of Uzbekistan. (2017, December 22). Послание Президента Республики Узбекистан Шавката Мирзиёева Олий Мажлису. https://president.uz/ru/lists/view/1371

Radio Free Europe Radio Liberty. (2021, April 25). Unable to get to Russia, thousands Of Uzbeks look to Kyrgyzstan for jobs. RadioFreeEurope/RadioLiberty. https://www.rferl.org/a/uzbeks-migration-kyrgyzstanjobs/31221668.html

Ravenstein, E. G. (1885). The Laws of migration. Journal of the Statistical Society of London, 48(2), 167-235.

RBC. (2019, August 16). ФСБ впервые за 20 мет раскрыла число приехавших работать иностранцев. РБК. https://www.rbc.ru/economics/16/08/2019/5d5560979a7947af4fa8a883

Republic of Turkey Ministry of Foreign Affairs. (2021). Relations between Turkey and Uzbekistan. Republic of Turkey Ministry of Foreign Affairs. https://www.mfa.gov.tr/relations-between-turkey-anduzbekistan $\% 20$.en.mfa

Sabates-Wheeler, R., \& Waite, M. (2003). Migration and social protection: A concept paper. Development Research Centre on Migration, Globalisation and Poverty.

Schenk, C. (2010). Open borders, closed minds: Russia's changing migration policies: Liberalization or xenophobia? Demokratizatsiya: The Journal of Post-Soviet Democratization, 18(2), 101-121. https://doi.org/10.3200/DEMO.18.2.101-121

Schmitz, A. (2020). Uzbekistan's transformation: Strategies and perspectives (Version 1) [SWP Research Paper 12]. Stiftung Wissenschaft und Politik German Institute for International and Security Affairs. https://www.swpberlin.org/10.18449/2020RP12/

Schulz, D. (2021, July 9). Russia loses credibility as Central Asian migrant destination. https://www.caspianpolicy.org/russia-loses-credibility-as-central-asian-migrant-destination/

Seitz, W. (2019). International migration and household well-being: Evidence from Uzbekistan Policy Research Working Paper 8910]. World Bank, Washington, DC. https://doi.org/10.1596/1813-9450-8910

Sibagatulina, Z. (2021). Embracing a dynamic future monumental shifts in Uzbek labour migration policy. Prague Process. https://www.pragueprocess.eu/en/migration-observatory/publications/document?id=284

Sigona, N., Kato, J., \& Kuznetsova, I. (2021). Migration infrastructures and the production of migrants' irregularity in Japan and the United Kingdom. Comparative Migration Studies, 9(1), 19. https://doi.org/10.1186/s40878021-00242-4

The Moscow Times. (2019, March 14). Kremlin seeks Russian-speaking migrants to offset population decline. The Moscow Times. https://www.themoscowtimes.com/2019/03/14/kremlin-seeks-russian-speaking-migrants-tooffset-population-decline-a64806

The Tashkent Times. (2017, August 2). Uzbekistan's development strategy for 2017-2021 has been adopted following public consultation. https://tashkenttimes.uz/national/541-uzbekistan-s-development-strategy-for2017-2021-has-been-adopted-following-discussion

TÜİK. (2020, July 17). Uluslararası göç istatistikleri 2019. https://data.tuik.gov.tr/Bulten/Index?p=UluslararasiGoc-Istatistikleri-2019-33709

UNESCAP. (2020, October 13). The good, the bad \& the ugly: Migration in North and Central Asia. ESCAP. https://www.unescap.org/blog/good-bad-ugly-migration-north-and-central-asia

United Nations. (2020). World population prospects 2019 - Volume II: Demographic profiles. UN. https://doi.org/10.18356/7707d011-en

United Nations, Department of Economic and Social Affairs. (2021, August 22). International Migrant Stock 2019. Population Division (2019). https://population.un.org/wpp/

United Nations, Department of Economic and Social Affairs. Population Division. (2019). International migrant stock $2019 \quad$ (United Nations database, POP/DB/MIG/Stock/Rev.2019). https://www.un.org/en/development/desa/population/migration/data/estimates2/estimates19.asp

UZSTAT. (2021). ВНЕШНЕТОРГОВЫЙ ОБОРОТ РЕСПУБАИКИ УЗБЕКИСТАН $\begin{array}{lllll}\text { (предварительныеданные } \quad \text { за } & \text { январь-декабрь } & 2020 & \text { года). }\end{array}$ https://stat.uz/images/uploads/docs/tashqi_savdo_dec_2020_ru.pdf

V.I. Vernadsky Crimean Federal University. (2015). Overview of rules on entry and residence of nationals of CIS member countries in the Russian Federation. https://eng.cfuv.ru/viza-i-migracionnaya-podderzhka/overviewof-rules-on-entry-and-residence-of-nationals-of-cis-member-countries-in-the-russian-federation

World Bank. (2021a). Foreign direct investment, net inflows (BoP, current US\$)—Uzbekistan | Data. https://data.worldbank.org/indicator/BX.KLT.DINV.CD.WD?locations=UZ

$\begin{array}{lllllll}\text { World Bank. (2021b). GDP per capita } & \text { (current } \$ \text { ) }\end{array}$ https://data.worldbank.org/indicator/NY.GDP.PCAP.CD

World Bank. (2021c, May). Migration and remittances data. World Bank. https://www.worldbank.org/en/topic/migrationremittancesdiasporaissues/brief/migration-remittances-data

Xiang, B., \& Lindquist, J. (2014). Migration infrastructure. International Migration Review, 48(S1), $122-148$. https://doi.org/10.1111/imre.12141

Yakubov, Y. (2021, July 12). Opportunities and limits of cooperation between Uzbekistan and Russia. CABAR.Asia. https://cabar.asia/en/opportunities-and-limits-of-cooperation-between-uzbekistan-and-russia 


\section{TÜRKÇE GENİ̧̧ ÖZET}

Sovyetler Birliği’nin dağılmasından sonra Orta Asya çeşitli sorunlarla birlikte göçle de karşı karşıya kalmış olup, başlangıçta etnik Kazak Kırgız, Özbekler kendi anavatanlarına dönerken daha sonra serbest piyasa ekonomisine geçişte yaşanan sorunlar Rusya'ya doğru işçi göçünü başlatmıştır. 3 milyondan fazla Özbek işçinin Rusya'da çalıştı̆̆ tahmin edilmekte olup, Özbek işçiler çoğunlukla mevsimsel ve kayıtsız olarak çalışmaktadır. Özbekistan, Orta Asya ülkeleri arasında nüfusu en çok olan ülkedir ve beş ülke çevrili olması uzun süre politikalarını savunma odaklı geliștirmesine yol açmıștır. Ayrıca, ülke çok sayıda demiryolu projesinin odağında yer aldığından komşu ülkeler dışında pek çok ülke için stratejik olarak önemlidir.

Özbekistan Başkan Mirziyoyev'in başa geçmesi ile ekonomi, dış politika ve göç yönetimi alanında Yeni Özbek Stratejisi çerçevesinde dönüşüm geçirmektedir. 2016 yllında başa geçen Shavkat Mirziyoyev "Hükümetin halka hizmet etmesinin zamanı geldi, tersi değil" slogan ile ülkenin ekonomik ve sosyal dönüşümü için 2017-2021 yıllarını kapsamak üzere "Yeni Özbek Stratejisi” hazırlamıştır. Böylece halkla yeni bir toplumsal sözleşme imzalanmış, diğer taraftan yeni bir bölgesel yaklaşım benimsenmiştir. Özbekistan işçi dövizlerinden önemli ölçüde yararlanmasına ve göçmen sayısına rağmen 2016 yllına kadar bu alanda fazla adım atmamışır. Düzenli ve güvenli göçün sağlanmasında, göçmenlerin varış ülkelerinde karşılaşabileceği kırılganlıklar ve risklerin üstesinden gelmek ve haklarının korunması açısından göç altyapısı önemlidir. Göçmenlerin kayıtsız çalışması varış ülkelerinde yoksulluk, dışlanma ve ayrımcllğga daha fazla hedef olmasına kırılganlıklarının artmasına ve marjinalleşmelerine yol açabilir. Bu makale, Özbekistan'ın göç altyapısını yurtdışındaki vatandaşların haklarının korunması ve sosyal bir süreç olarak Yeni Özbek Stratejinden hareketle incelemeyi amaçlamaktadır. Göç altyapısı kavramı yeni bir kavram değildir ancak, Çin, Endonezya, Filipinler gibi bazı ülkeler için göç altyapısına ilişkin çalışmalar bulunmakla birlikte Özbekistan için böyle bir çalışmaya rastlanmamıştır. Dolayısıyla, bu araştırmanın göç altyapısının göçü başlatma ve göçün yöneleceği ülkeleri belirlemede katkısı olacağı düşünülmektedir.

Göç disiplinler arası bir alan olup, teoriler göç kararını açıklamayı hedeflemektedir. İşlevselci paradigma çerçevesinde Lee'nin itme ve çekme yaklaşımı, göç sistemleri teorisi, göçmen ağları ele alınabilirken, bu yaklaşım göç kararına ilişkin itme çekme teorisinde olduğu gibi bir liste sunmakta ve söz konusu bileşenlerin birbiri ile ilişkisini ya da göçü sosyal süreç olarak anlamakta yetersiz kalabilmektedir. Göç ekonomik, sosyal, siyasal pek çok faktörden etkilenmektedir. Xiang ve Lindquist (2014), Çin ve Endonezya'ya ilişkin araştırmalarında göç altyapısı kavramını kullanmış olup, göç altyapısı teknolojik, düzenleyici, ticari, insani ve sosyal olmak üzere beş bileşenden oluşmaktadır. Söz konusu kavram göçün kolaylaştırılması ve düzenlenmesini sağlamakta, davranışlardan çok yapıya odaklanmakta bu nedenle belli ölçüde kararlılık içermektedir. Dolayısıyla, Özbekistan'daki yapısal dönüşümü anlamak için ekonomik teoriler yerine bu kavram kullanılmıştır.

İtme ve çekme faktörlerinden hareket edildiğinde göç genellikle ekonomik, demografik, politik, sosyal ve kültürel faktörlerle açıklanmaktadır. Ancak, sadece göç kararını etkileyen bileşenleri açıklayarak göçü sosyal bir süreç olarak, yapısal olarak anlamak güçtür. Göç kararı itme ve çekme faktörleri ile açıklandığında dil, göçmen ağları ve kültürel yakınlık Rusya, Kazakistan ile Türkiye’ye yönelen göçü açıklamakta kullanılabilmektedir. Özbekistan'ın en büyük beş ticari ortağı Çin, Rusya, Kazakistan, Güney Kore ve Türkiye'dir. Dil ve kültürel farklllıklara rağmen Güney Kore ve Japonya'ya göç artmaktadır. Diğer taraftan, Özbekistan ile Türkiye ve Rusya arasında olan vizesiz seyahat göçmenlerin işçi olarak kayıtları olmadan bu ülkelerde çalışabilmelerini sağlamakla birlikte bu durum verilerin eksik olmasına ve kişilerin haklarının korunamamasına yol açabilmektedir. Özbekistan'dan göç için ekonomi ve demografi önemini korumakla birlikte Güney Kore ve Japonya'ya göç kültürel yakınlık ve dilin öneminin azaldığını göstermektedir. Ayrıca varış ülkeleri açısından göçmenlerin ulusal kimlik ya da güvenlik açısından tehdit olarak görülebileceği de unutulmamalıdır.

Yeni Özbek Stratejinde yer alan ekonomik serbestleşme, yapıcı dış politika ve güvenlik faaliyetleri göç altyapısının gelişmesini sağlamaktadır. Özbekistan, önleyici ve dönüştürücü bir seri politika ile düzenli ve güvenli göçü sağlamayı ve yurtdışında vatandaşlarına yasal destek sunmayı ve sosyal koruma sağlamayı hedeflemektedir. Yeni Strateji ile öncelikle Çalışma Bakanlığının yapısı değiştirilmiş, Yurtdışı İşçi Göçü Ajansı kurulmuştur. Diğer taraftan işçi göçüne aracılık etmek üzere İstanbul, Dubai ile Rusya'nın beş şehrinde ofis kurulması kararı alınmıştır. Ayrıca, ülke içinde yurtdışında çalışacaklar için özel işe alma şirketleri kurulmasına izin verilmiştir. Yurtdışında yaşayan ve sosyal, finansal veya yasal yardıma ihtiyacı olan kişilere destek olmak sağlık masraflarını karşılamak için bir fon uygulaması başlatılmıştır. Göçmen 
işçilerin kapasitelerini artırmak amacıyla dil ve uyum eğitimleri verilmektedir. Tüm bu faaliyetler göç altyapısının düzenleyici ve ticari boyutunu oluşturmaktadır. Yapıcı dış politika, dış ekonomik faaliyetler, komşularla iyi ilişkiler, ikili ve çok taraflı anlaşmalar da göç altyapısının düzenleyici boyutunu güçlendirmektedir. Komşularla iyi ilişkiler çerçevesinde Orta Asya ülkeleri, Güney Kore, Rusya, Çin ve Türkiye ile yapılan anlaşmalarda ticaretin artırılmasının yanında göçmenlerin güvenliği de gündem maddeleri arasındadır. Çin'in Tek Kuşak Tek yol Projesi, İran demiryolu, Afganistan demiryolu projeleri ise bölgede ulaşımla birlikte, limanlara erişmeyi, göçü, turizmi ve yatırımların artmasını sağlayacak projeler olarak göç altyapısının teknolojik bileşenini oluşturmaktadır. Diğer taraftan IOM, ILO, GIZ, Dünya Bankası gibi uluslararası kuruluşlarla yürütülen işbirlikleri göç altyapısının insani boyutunu oluşturmaktadır. Rusya, Afganistan gibi ülkelerde yaşayan Özbek azınlıklar ile Türkiye, Pakistan, Suudi Arabistan gibi ülkelerdeki çalışan işçilerden oluşan Özbek Diasporası göç altyapısının sosyal boyutu olan göç ağlarını güçlendirmektedir. Dolayısıyla, göç altyapısı yalnızca ekonomik reformlarla değil yapıcı dış politika ile de desteklenmektedir. Xiang ve Lindquist göç altyapısındaki bir bileşenin büyümesinin diğerlerinin gelişmesini tetikleyeceğini belirtmektedir. Özbekistan göç altyapısı bu çerçevede özellikle düzenleyici ve ticari bileşenlerindeki ilerleme açıkça görülmektedir. Rusya, Türkiye ve Kazakistan’a göç kültürel yakınlık ve dille açıklanabilirken Güney Kore ve Japonya'ya gerek işçi gerek eğitim amaçlı göç artmış olup, bu ülkelere göç ancak göç altyapındaki gelişmelerle açıklanabilmektedir.

Sonuç olarak, Yeni Özbek Stratejinin etkisini değerlendirmek için erken olmasına rağmen göç altyapısının tüm bileşenlerinde bir ilerleme görülmektedir. Ekonomik serbestleşme ile birlikte dış politika da göç altyapısını güçlendirmek amacıyla kullanılmaktadır. Göç altyapısına ilişkin adımların Rusya, Türkiye ve Kazakistan dışında Güney Kore ve Japonya'ya göçü artırabileceği tahmin edilmektedir. Göçün kurumsallaşmasının Özbekistan'ın dönüşümü ve ekonomik büyümeye katkıda bulunması beklenmektedir. 